\title{
Impacts of anthropogenically influenced groundwater seepage on water chemistry and phytoplankton dynamics within a coastal marine system
}

\author{
Christopher J. Gobler ${ }^{1, *}$, George E. Boneillo ${ }^{2}$ \\ ${ }^{1}$ Natural Science Division, Southampton College of Long Island University, Southampton, New York 11968, USA \\ ${ }^{2}$ Present address: Department of Ocean, Earth and Atmospheric Sciences, Old Dominion University, Norfolk, \\ Virginia 23529-0276, USA
}

\begin{abstract}
Although landfills are a common method of solid-waste disposal, reports describing the impact of landfill leachate discharge on coastal surface-water quality are rare. In order to establish the impact of anthropogenically influenced groundwater seepage on a specific coastal marine ecosystem, a field campaign was conducted within North Sea Harbor (NSH), New York, USA, an embayment located northwest of, and down-gradient from, an unlined, municipal landfill. Most groundwater entering this system had modest seepage rates $\left(0.020\right.$ to $\left.1.18 \mathrm{~cm} \mathrm{~h}^{-1}\right)$, was welloxygenated $(278 \pm 128 \mu \mathrm{M})$, contained moderate levels of nitrate/nitrite $(57 \pm 26 \mu \mathrm{M})$ and ammonium $(5.9 \pm 13 \mu \mathrm{M})$, and had low dissolved organic carbon levels (DOC $=71 \pm 21 \mu \mathrm{M})$. In contrast, groundwater entering the SE portion of NSH was indicative of a landfill leachate plume, with high ammonium $(>1 \mathrm{mM})$, and DOC $(520 \pm 270 \mu \mathrm{M})$ levels, low oxygen $(20.3 \pm 15.3 \mu \mathrm{M})$ and nitrate/nitrite $(11 \pm 8.9 \mu \mathrm{M})$ concentrations, and elevated seepage rates $\left(8.33 \pm 4.54 \mathrm{~cm} \mathrm{~h}^{-1}\right)$. Quantification of inorganic nitrogen fluxes revealed that seepage of this ammonium-rich groundwater accounted for $\sim 80 \%$ of the inorganic $\mathrm{N}$ supply to the embayment receiving the discharge. The water column adjacent to this landfill-influenced groundwater seepage exhibited high levels of ammonium (61.7 \pm $69.3 \mu \mathrm{M})$ and chlorophyll $\left(8.4 \pm 4.1 \mu \mathrm{g} \mathrm{l}^{-1}\right)$, and hosted a microphytoplankton community that was comprised primarily of dinoflagellates and was N-replete. This contrasted with neighboring, nonleachate-influenced areas which had low ammonium $(0.6 \pm 0.6 \mu \mathrm{M})$ and chlorophyll $\left(1.7 \pm 0.7 \mu \mathrm{g} \mathrm{l}^{-1}\right)$ levels and an N-limited microphytoplankton community dominated by diatoms. In summary, these results demonstrate that discharge of groundwater containing landfill leachate may be a significant, long-term eutrophication process in coastal environments.
\end{abstract}

KEY WORDS: Groundwater - Phytoplankton - Nutrients · Nutrient limitation - Nutrient ratios · Landfill leachate

Resale or republication not permitted without written consent of the publisher

\section{INTRODUCTION}

Eutrophication of coastal waters can have a multitude of adverse impacts on affected ecosystems, including nuisance algal blooms, hypoxia, and the subsequent loss of marine life and habitats (de Jonge et al. 2002). Traditionally, research on coastal eutrophication has focused on large point sources of nutrients, such as rivers and sewage treatment plants (Richardson \&
Jørgensen 1996). Recent studies of shallow estuarine environments have also demonstrated that groundwater that has been impacted by coastline urbanization or agriculture can be a substantial nutrient delivery pathway. For example, groundwater seepage is the primary source of nitrogen in many estuaries along the east coast of the United States (Lee \& Olsen 1985, Giblin \& Gaines 1990, Valiela et al. 1992, Staver \& Brinsfield 1996, LaRoche et al. 1997). Since nitrogen limits 
primary production in many coastal environments (Nixon \& Pilson 1983, Borum 1996), nutrient loading from groundwater seepage has been shown to greatly impact algal dynamics (Johannes 1980, Sewell 1982, Kinney \& Roman 1998), harmful algal blooms (LaRoche et al. 1997, Gobler \& Sañudo-Wilhemy 2001) and entire ecosystems (Valiela et al. 1992, Short \& Burdick 1996, McClelland et al. 1997).

The most common method of waste disposal in the United States is landfill burial (EPA 1997). The infiltration of rainfall through older, unlined landfill waste can create leachate plumes, which traverse through groundwater aquifers along prevailing hydraulic gradients (Freeze \& Cherry 1979, Fetter 1994). Since landfill leachate plumes are typically enriched in nitrogen and phosphorus (Bjerg et al. 1995, Cozzarelli et al. 2000, Christensen et al. 2001), they may contribute to eutrophication of aquatic systems. Moreover, the short distance between coastal landfills and nearshore discharge of groundwater may prevent substantial hydrodynamic dispersion, microbial degradation, and/or retention of such plumes (Fetter 1994, Christensen et al.

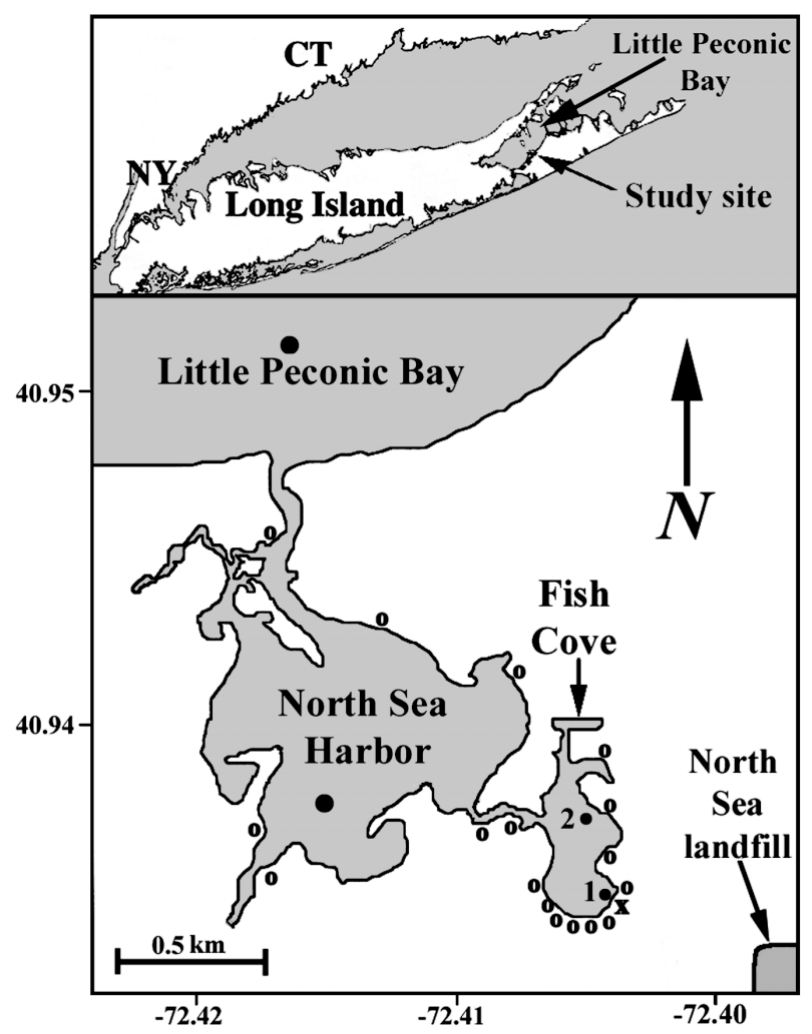

Fig. 1. Study sites, Fish Cove, North Sea Harbor and Little Peconic Bay (Sites 1 and 2). (•) Sampling locations; (o) normal groundwater sampling sites, $(\mathbf{x})$ site of high-flow groundwater discharge associated with North Sea landfill. Gray square in lower right corner map depicts northwest extent of North Sea landfill
2001). To date, there have been numerous reports of landfill leachate plumes discharging into coastal waters (Striebel et al. 1991, Chu et al. 1994, Furukawa et al. 1994, Walsh \& LaFleur 1995, Nobes et al. 2000, Barlaz et al. 2002). Although the impact of landfill leachate on groundwater composition has been well studied (see review by Christensen et al. 2001), the potential effects of leachate plume discharge on coastal water quality and plankton communities are largely unknown.

\section{MATERIALS AND METHODS}

Study site. The Peconic Estuary encompasses approximately $250 \mathrm{~km}^{2}$ between the North and South Forks of eastern Long Island, NY (Fig. 1). The aquifer surrounding the Peconic Estuary contains a layering of hydraulically distinct freshwater lenses, bounded by salt water, within a vertical sequence of unconsolidated deposits. Groundwater seepage has been identified as the primary source of freshwater and nitrogen to the Peconic Estuary (LaRoche et al. 1997), and interannual variability in groundwater flow has been shown to influence the occurrence of harmful browntide algal blooms within the estuary (LaRoche et al. 1997, Gobler \& Sañudo-Wilhelmy 2001).

North Sea Harbor is a small $\left(\sim 1.1 \mathrm{~km}^{2}\right)$, shallow (2 to $4 \mathrm{~m})$, enclosed embayment located along the southern shores of the Peconic Estuary (Fig. 1). The harbor tidally exchanges with Little Peconic Bay of Peconic Estuary through an inlet in its northern extent and with a small $\left(\sim 0.13 \mathrm{~km}^{2}\right)$ confined embayment called Fish Cove through a tidal inlet within its SE reaches (Fig. 1). In 1963, the North Sea landfill was constructed $\sim 500 \mathrm{~m}$ SE of the North Sea Harbor system to dispose of municipal solid and septic wastes (Fig. 1). While portions of the landfill are still active, several older, unlined cells of the landfill, which received more than $10^{6} \mathrm{~m}^{3}$ of solid and septic waste, were capped in 1985. The relatively high elevation of the landfill $(75 \mathrm{~m}$, one of the highest elevations on Long Island's south fork) and its close proximity to the North Sea Harbor system (500 m) combine to create a steep hydraulic gradient for groundwater recharging through the landfill. This steep gradient, along with a confining clay lense $<25 \mathrm{~m}$ below the landfill, have contributed towards the creation of a concentrated leachate plume emanating from unlined cells of the North Sea landfill that discharges into the SE corner of Fish Cove. While previous investigations by municipal agencies have identified groundwater and drinking waters wells between the North Sea landfill and Fish Cove which have been contaminated by the leachate plume (EPA 1984, 1989), the impacts of this plume on surface water quality in Fish Cove and North Sea Harbor have not been documented. 
The objective of this study, therefore, was to evaluate how groundwater emanating from the North Sea landfill may impact water quality and phytoplankton dynamics within North Sea Harbor and its adjacent waters. During 2000 and 2001, groundwater seepage rates were quantified around Fish Cove and North Sea Harbor, while inorganic nutrients potentially affecting phytoplankton growth were simultaneously measured in the water column of the North Sea Harbor system and in groundwater entering the area. Inorganic nitrogen fluxes were quantified to evaluate the importance of groundwater seepage to the overall supply of nitrogen to this system. Phytoplankton biomass and species diversity were quantified throughout the region, and nutrient limitation of phytoplankton growth rates was experimentally evaluated on a monthly basis.

Sample collection. From March 2000 to September 2001, groundwater entering Fish Cove and North Sea Harbor was sampled by shallow $(1 \mathrm{~m})$ PVC piezometers with $2.5 \mathrm{~cm}$ long, horizontal screened slits along the lower $25 \mathrm{~cm}$, placed within the intertidal zone (Fig. 1). Previous research on eastern Long Island has demonstrated that groundwater collected with such piezometers is more representative of the groundwater which enters surface waters than groundwater collected from coastal wells (Gobler \& Sañudo-Wilhemy 2001). High groundwater flow rates within seeps typically allowed intertidal samplers to fill with fresh groundwater (salinity <0.1 PSU) when sampled between $1 \mathrm{~h}$ before and $1 \mathrm{~h}$ after low tide. Piezometers were sampled using a low-flow $\left(<100 \mathrm{ml} \mathrm{min}^{-1}\right)$, peristaltic pump equipped with acid-washed Teflon tubing. Dissolved oxygen, temperature, and conductivity levels of pumped groundwater were measured with submersible electrodes placed in a flow-through sampling cell (Geo Tech Environmental Equipment ${ }^{\odot}$ ). To ensure that representative groundwater was obtained, samples were not collected until the dissolved oxygen, temperature, and conductivity of the pumped groundwater stabilized, which was typically $0.5 \mathrm{~h}$ (Puls \& Powell 1992, Puls \& Paul 1995). DOC, nutrient and salinity samples were filtered with acid-cleaned, polypropylene capsule filters $(0.2 \mu \mathrm{m}$; MSI) or precombusted GF/F glass-fiber filters in the field, and immediately stored on ice. Within $2 \mathrm{~h}$, DOC samples were acidified with quartz-distilled nitric acid and frozen along with nutrient samples.

From March 2000 to January 2001, seawater samples were collected weekly to bi-weekly from a small boat at stations within Fish Cove (Sites 1 and 2), North Sea Harbor, and Little Peconic Bay (Fig. 1). These locations allowed direct comparison of the site directly receiving groundwater originating from the landfill to other enclosed embayment sites and to the estuary hosting these embayments. Samples were collected using 4 l, acid-washed fluorinated LDPE (low density polyethlene) bottles, which were rinsed with distilleddeionized water and filled $0.5 \mathrm{~m}$ below the water surface. In August 2000, a 16-station transect was made from Fish Cove to Little Peconic Bay. After water collection, triplicate chl a samples were collected on GF/F glass-fiber filters, and stored frozen. Chlorophyll a was size-fractionated using a $5 \mu \mathrm{m}$ Nitex $^{\odot}$ mesh (Gobler \& Sañudo-Wilhelmy 2001). Nutrient samples were filtered with precombusted GF/F glass-fiber filters and immediately frozen. Whole seawater samples were preserved in Lugol's iodine and in $1 \%$ gluteraldhyde for microscopic examination of phytoplankton.

Sample analyses. DOC samples were analyzed in duplicate by high-temperature catalytic oxidation using a Shimadzu TOC-5000 total organic carbon analyzer (Benner \& Strom 1993). Measurements of J. Sharp's (University of Delaware) intercalibration DOC samples were within $5 \%$ of the consensus value. Salinity was measured with a YSI 85 probe. Measurements were confirmed on a Beckman ${ }^{\odot}$ induction salinometer (Model RS 7B). Chlorophyll a ( $\mathrm{chl} \mathrm{a}$ ) was analyzed in triplicate by standard fluorometric methods (Parsons et al. 1984). Nitrate/nitrite (Jones 1984), silicate, phosphate and ammonium (Parsons et al. 1984) were analyzed in duplicate by standard spectrophotometric methods. Recoveries of SPEX Certi-Prep ${ }^{\mathrm{INC}}$ inorganic nutrient standard-reference material were $104 \pm 5 \%$ for nitrate, $96 \pm 6 \%$ for ammonium, and $103 \pm 11 \%$ for phosphate. Precombustion of glassware and GF/F filters provided adequately low blanks for DOC $(<10 \%$ of lowest sample). Selected preserved plankton samples were settled in counting chambers and enumerated with an inverted light microscope (Hasle 1978). Settled micro-phytoplankton $(>10 \mu \mathrm{m})$ were identified to genus or species level and were generally grouped into the following major taxa: diatoms, dinoflagellates, and raphidophytes.

Estimation of groundwater flow rates and recharge. Three independent estimates of groundwater flow around North Sea Harbor were made during this study: (1) groundwater seepage rates were determined with an ultrasonic seepage meter (Paulsen et al. 2001); or (2) by traditional funnel chambers (Lee 1977, Belanger \& Montgomery 1992, Cable et al. 1997); (3) the recharge rate of aquifer surrounding North Sea Harbor was calculated according to Steenhuis et al. (1985). The ultrasonic groundwater seepage meter consisted of a steel collection funnel, which contained 2 piezoelectric transducers mounted at opposite ends of a cylindrical flow tube (Paulsen et al. 2001). Perturbations in fluid flow were monitored from the propagation of sound waves inside the flow tube. This device allowed for real-time field measurements of forward and reverse groundwater seepage on the order of 
$0.1 \mathrm{~m} \mathrm{~s}^{-1}$ over several days in July 2000. To ensure that ultrasonic seepage meters remained submerged throughout the tidal cycles, they were placed $1 \mathrm{~m}$ beyond the intertidal zone.

Groundwater seepage chambers (Lee 1977, Belanger \& Montgomery 1992, Cable et al. 1997) were deployed throughout the North Sea Harbor system during high (March and April) and low (August and September) groundwater-flow periods (Steenhuis et al. 1985). The seepage chambers were fitted with 51 'Ziploc' bags pre-filled with $1 \mathrm{l}$ of seawater, and seepage volumes were corrected for salinity (Cable et al. 1997). Since tidal stage can significantly impact groundwater flow rates in the Peconic Estuary (Paulsen et al. 1998, 2001), the bags were fitted on seepage meters throughout a $6 \mathrm{~h}$ tidal cycle (high to low tide) to ensure that seepage rates were representative of high and low tides. Because of high seepage rates in the SE portion of Fish Cove, bags were retrieved from seepage meters after $2 \mathrm{~h}$ periods during both high and low tide.

The volume of groundwater recharging the North Sea Harbor-Fish Cove watershed was estimated using the methods of Steenhuis et al. (1985), who determined that seasonal changes in evapotranspiration is the process which has the greatest influence on groundwater recharge on eastern Long Island. This method has been used successfully in the past to calculate groundwater discharge and recharge rates into Long Island embayments (Gobler \& Sañudo-Wilhelmy 2001, Montluçon \& Sañudo-Wilhelmy 2001), where recharge rates are generally comparable to groundwater discharge rates (Schubert 1998). The watershed areas for Fish Cove and North Sea Harbor were determined from US Geological Survey water-table maps of Long Island's South Fork watershed (Schubert 1998). Mean daily recharge rates $\left(2.0 \times 10^{7} 1 \mathrm{~d}^{-1}\right)$, calculated according to Steenhuis et al. (1985), were similar to those previously calculated for the NSH region using independent methods $\left(2.5 \times 10^{7} 1 \mathrm{~d}^{-1}\right.$; Schubert 1998).

Inorganic nutrient fluxes. The supply of inorganic nitrogen to Fish Cove and North Sea Harbor was estimated in order to establish the relative contribution of various sources to these systems. Nitrogen input fluxes considered included tidal exchange, precipitation/ atmospheric deposition, land run-off, diffusive benthic fluxes, groundwater seepage, and creeks. Groundwater discharge volumes were calculated as described above (Steenhuis et al. 1985). Groundwater seepage rates within the high-flow landfill-plume area were obtained from direct seepage-meter measurements. Precipitation data were obtained from the Brookhaven National Laboratory (V. Cassella pers. comm.), which is $\sim 25 \mathrm{~km}$ west of the study site. Concentrations of dissolved inorganic nitrogen (DIN) in precipitation were obtained from Cornell et al. (1995). Atmospheric deposition fluxes (wet and dry) were calculated according to Paerl (1993) and Hu et al. (1998). Run-off volumes ( $5 \%$ of precipitation to the watershed) and estimates of DIN concentrations in the run-off were obtained from a study of a similarly sized, enclosed embayment on eastern Long Island (Gobler 1999). Annual diffusive benthic fluxes of DIN measured in bays of the Peconic Estuary with sediment composition similar to Fish Cove and North Sea Harbor were obtained from Howes et al. (1998). Howes et al. (1998) determined these fluxes using $24 \mathrm{~h}$ sediment-core incubation at in situ light and temperature conditions, as described by Howes \& Goehringer (1994). DIN concentrations in the water column and groundwater seepage were averages from this study. Tidal exchange volumes were calculated using a salt balance (Fischer et al. 1979) between Fish Cove and North Sea Harbor and between North Sea Harbor and Little Peconic Bay (Fig. 1) according to the following equation:

$$
Q_{\mathrm{T}}=\left(Q_{\mathrm{GW}}+Q_{\mathrm{RO}}+Q_{\text {precip }}+Q_{\mathrm{C}}\right) /\left[1-\left(S_{\mathrm{B}} / S_{\mathrm{T}}\right)\right]
$$

where $Q$ represents the water fluxes from net tidal exchange (T), groundwater (GW), surface run-off (RO), precipitation (precip) and creeks (C), and $S$ is the mean annual salinities for the body of water of interest (B) and the tidally exchanging body of water (T).

Nutrient-addition experiments. Nutrient-addition experiments were conducted to determine if $\mathrm{N}$ or $\mathrm{P}$ controlled phytoplankton growth rates in the North Sea Harbor region. Within $1 \mathrm{~h}$ of collection, seawater collected from Fish Cove Site 1, North Sea Harbor, and Little Peconic Bay was transferred to $250 \mathrm{ml}$, acidcleaned, experimental polycarbonate flasks. Triplicate flasks were amended with sodium nitrate $(10 \mu \mathrm{M})$, ammonium chloride $(10 \mu \mathrm{M})$ or sodium phosphate $(1 \mu \mathrm{M})$, or were left unamended as a control treatment. Nitrate was used as the $\mathrm{N}$ source during April, May and June, while ammonium was used in July, August, September, and October. This shift in $\mathrm{N}$ sources was used to match the prevailing inorganic $\mathrm{N}$ source available to resident phytoplankton communities, as nitrate is typically the dominant $\mathrm{N}$ source in the cooler spring months, and regenerated forms of $\mathrm{N}$, such as ammonium, are more abundant during the summer and fall (Bruno et al. 1983, Gobler \& Sañudo-Wilhemly 2001). The concentrations of experimental nutrient additions were similar to previously observed increases of these nutrients in the water column of Peconic Estuary embayments on Long Island (Gobler \& SañudoWilhemly 2001, this study). Nutrient stocks were filtersterilized $(0.2 \mu \mathrm{m})$ and stored frozen. Experimental bottles were incubated at a depth of $\sim 0.25 \mathrm{~m}$ under 2 layers of neutral-density screening $(65 \%$ reduction in ambient light) in Old Fort Pond (OFP) at the 
Table 1. Groundwater seepage rates measured around North Sea Harbor-Fish Cove system. North Sea Harbor and Fish Cove non-plume sites correspond to 'o' sites in Fig. 1, while Plume sites correspond to ' $\mathbf{x}$ ' site. Spring samplings were conducted in March and April 2000, late summer samplings in August and September 2001. Funnel: traditional seepage meter; Ultrasonic: ultrasonic seepage meter

\begin{tabular}{|lllrr|}
\hline Location & Method & $\begin{array}{c}\text { Time of } \\
\text { sampling }\end{array}$ & $\begin{array}{c}\text { Seepage rate } \\
\left(\mathrm{cm} \mathrm{h}^{-1}\right)\end{array}$ & $\mathrm{n}$ \\
\hline North Sea Harbor & Funnel & Annual mean & $0.020 \pm 0.008$ & 12 \\
Fish Cove, non-plume & Funnel & Annual mean & $0.118 \pm 0.041$ & 14 \\
Plume & Funnel & Annual mean & $8.333 \pm 4.546$ & 22 \\
Plume & Funnel & Spring & $10.503 \pm 3.677$ & 14 \\
Plume & Funnel & Late summer & $7.031 \pm 4.597$ & 22 \\
Plume & Ultrasonic & Late summer & $6.460 \pm 5.775$ & 570 \\
& & & & \\
\hline
\end{tabular}

Southampton College Marine Station, located $5 \mathrm{~km}$ south of North Sea Harbor. Open tidal exchange with Shinnecock Bay keeps OFP well flushed; temperatures during incubations were typically within $2^{\circ} \mathrm{C}$ of stations in North Sea Harbor. After $24 \mathrm{~h}$, experimental flasks were filtered for chl a onto GF/F glass-fiber filters. Net growth rates of the total phytoplankton community were calculated from changes in chl a using the formula:

$$
k=\left[\ln \left(B_{t} / B_{\mathrm{o}}\right)\right] / t
$$

where $k$ is the net relative growth rate, $B_{t}$ is the amount of biomass ( $\mathrm{chl} \mathrm{a}$ ) present at the end of the experiments, $B_{0}$ represents the amount of biomass at the beginning of experiments, and $t$ is the duration of the experiment in days (Guillard 1973).

\section{RESULTS}

\section{Groundwater flow rates and composition}

Mean shoreline groundwater flow rates as determined by traditional seepage meters were generally lower around North Sea Harbor $\left(0.020 \pm 0.008 \mathrm{~cm} \mathrm{~h}^{-1}\right.$; Table 1) compared to areas surrounding Fish Cove $\left(0.118 \pm 0.040 \mathrm{~cm} \mathrm{~h}^{-1}\right.$; Table 1$)$. Within the $\mathrm{SE}$ corner of Fish Cove, there was a focal point of heavy groundwater flow, which consisted of freshwater springs and large seeps. In this region, up to $10 \mathrm{~cm}$ of fresh groundwater flowed above red, iron-stained, coarse sediments along the shoreline. Rates of groundwater flow measured by traditional seepage meters in this area were very high (8.33 $\pm 4.54 \mathrm{~cm} \mathrm{~h}^{-1}$; Table 1$)$, and not statistically different from those measured with ultrasonic seepage meters $\left(6.46 \pm 5.77 \mathrm{~cm} \mathrm{~h}^{-1}\right.$; Table 1$)$. Rates of groundwater seepage within this plume followed a seasonal pattern, with funnel-measured flow rates during a spring survey (March 2000: $10.5 \pm 3.68 \mathrm{~cm} \mathrm{~h}^{-1}$; Table 1) being greater than those observed during a late summer survey (August 2001: $7.03 \pm 4.59 \mathrm{~cm} \mathrm{~h}^{-1}$; Table 1).

The chemical composition of groundwater entering most areas around Fish Cove and North Sea Harbor (sites marked 'o' in Fig. 1) was similar (Fig. 2). This piezometer-collected groundwater seepage was partially oxygenated dissolved oxygen $(\mathrm{DO}=278 \pm$ $128 \mu \mathrm{M})$, contained moderate levels of nitrate/nitrite $(57 \pm 26 \mu \mathrm{M})$, silicate $(67 \pm$ $47 \mu \mathrm{M})$ and DOC $(71 \pm 22 \mu \mathrm{M})$, and had lower levels of phosphate $(0.68 \pm$ $0.41 \mu \mathrm{M})$ and ammonium $(5.9 \pm 13 \mu \mathrm{M}$; Fig. 2). Groundwater emanating from the SE corner of Fish Cove (' $\mathbf{x}^{\prime}$ in Fig. 1), however, was markedly different from that at other sites in the region. Groundwater within this $\sim 30 \mathrm{~m}$-wide plume of high seepage was nearly anoxic (DO = 20.3 $\pm 15.3 \mu \mathrm{M}$; Fig. 2) and contained high levels of ammonium (942 \pm $347 \mu \mathrm{M})$ and DOC (520 $\pm 259 \mu \mathrm{M}$; Fig. 2). Concentrations of silicate $(86 \pm 40 \mu \mathrm{M})$ and phosphate $(0.93 \pm$ $0.55 \mu \mathrm{M})$ in the groundwater of this region were slightly higher than in other areas surrounding Fish Cove and North Sea Harbor (Fig. 2), while nitrate/nitrite levels $(10.9 \pm 8.48 \mu \mathrm{M})$ were significantly lower (Fig. 2).

Zones of rapid transition in groundwater composition were noted across the width of the high-flow groundwater area entering the SE corner of Fish Cove (Fig. 3). On the fringes of the high flow plume (>25 $\mathrm{m}$ from the center), groundwater was partly oxygenated $(>100 \mu \mathrm{M})$, contained modest levels of nitrate/nitrite $(\sim 50 \mu \mathrm{M})$ and low ammonium concen-

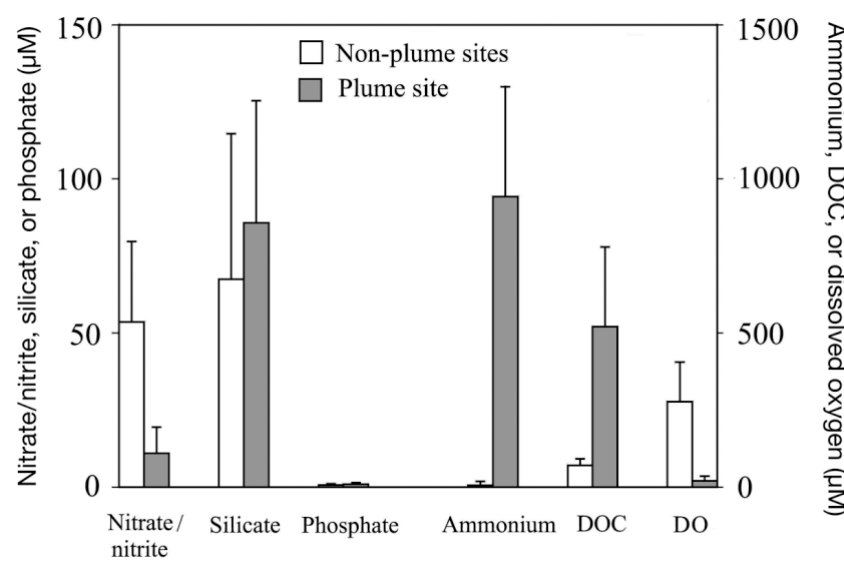

Fig. 2. Mean ( $\pm 1 \mathrm{SD})$ levels of nitrate/nitrite, silicate, phosphate ammonium, dissolved organic carbon (DOC) and dissolved oxygen (DO) from high-flow groundwater plume site in Fish Cove (Site ' $\mathbf{x}$ ' in Fig. 1) and non-plume sites around Fish Cove and North Sea Harbor ('o' in Fig. 1) 


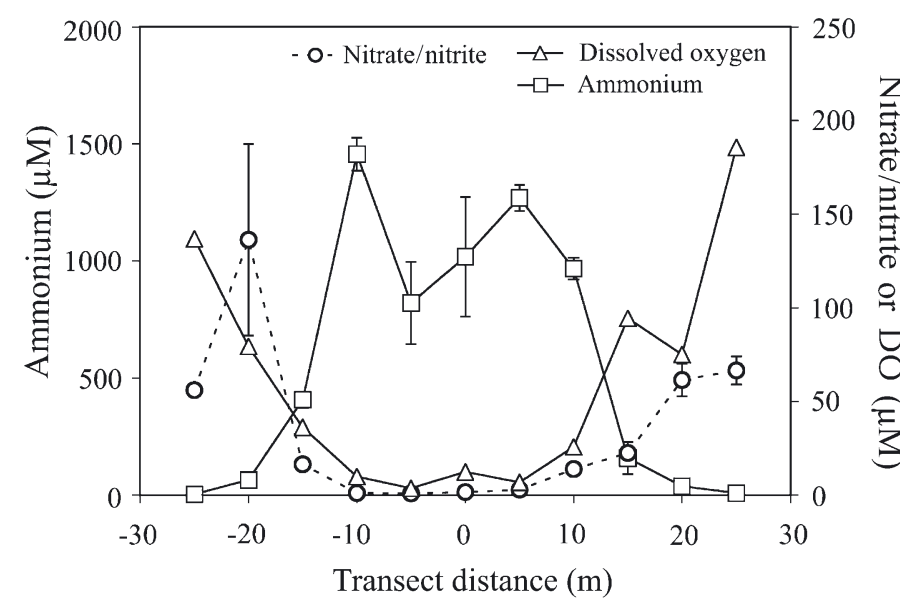

Fig. 3. Mean ( $\pm 1 \mathrm{SD})$ levels of ammonium, nitrate/nitrite and dissolved oxygen (DO) in high-flow groundwater in southeast corner of Fish Cove. Distances are relative to discharge plume center, with distances to the east being negative and distances to the west positive

trations $(<5 \mu \mathrm{M}$; Fig. 3), while $15 \mathrm{~m}$ to the east or west of the plume center, oxygen levels dropped below $50 \mu \mathrm{M}$, ammonium levels rose above $1000 \mu \mathrm{M}$, and nitrate/nitrite levels decreased (Fig. 3). We did not observe any significant temporal variation in the chemical composition of groundwater entering Fish Cove and North Sea Harbor from March 2000 to September 2001. This observation is consistent with other studies of groundwater composition on eastern Long Island that have noted an absence of temporal variability in groundwater composition (Gobler \& Sañudo-Wilhelmy 2001).

\section{Surface-water nutrients and nutrient ratios}

A transect made from the site of the high-flow groundwater plume in Fish Cove to Little Peconic Bay illustrated the impact of the discharging groundwater on salinity and ammonium levels of surface waters in Fish Cove and the surrounding region. Within $10 \mathrm{~m}$ of the discharge site, salinities rose sharply from 2.8 to 24 PSU, and levels of dissolved ammonium ranged from 100 to $600 \mu \mathrm{M}$ (Fig. 4A,B). Progressing $500 \mathrm{~m}$ seaward through Fish Cove, salinities rose slightly from 24 to 27 PSU, while ammonium gradually declined from 69 to $5.8 \mu \mathrm{M}$ (Fig. 4A,B). At sites located in North Sea Harbor and Little Peconic Bay, salinities increased to $28 \mathrm{PSU}$, and ammonium concentrations were low ( 0.5 to $1.3 \mu \mathrm{M}$; Fig. $4 \mathrm{~A}, \mathrm{~B}$ ). A mixing curve of salinity and ammonium through this transect, which used groundwater seepage as the freshwater endmember (Fig. 4C), was visually similar to the mixing of river water and estuarine seawater (Sharp et al. 1984), but indicated ammonium removal of through the transect. A Model I linear regression of all points excluding the freshwater end member was more linear $\left(r^{2}=0.97\right)$, and yielded a freshwater end member ( $y$-intercept) of $625 \mu \mathrm{M}$ (Fig. 4C).

In a manner consistent with the transect data, Site 1 in Fish Cove, which was directly adjacent to the highflow groundwater plume, had high levels of dissolved inorganic nitrogen and salinities which were lower than adjacent embayments throughout our 2000 and
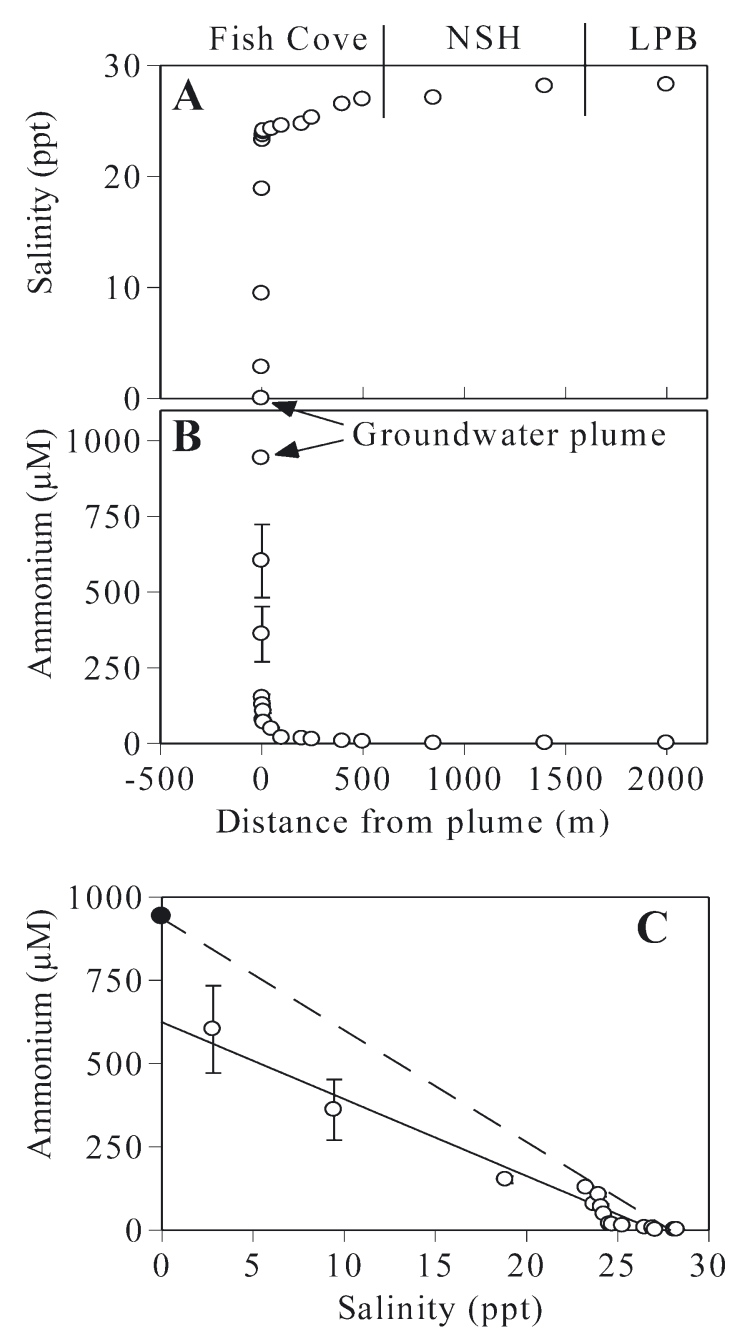

Fig. 4. Mean $( \pm 1 \mathrm{SD})$ changes in salinity, ammonium and in salinity and ammonium in horizontal water-column transect from Fish Cove to Little Peconic Bay, 26 July 2000 (•) Mean level of ammonium within Fish Cove groundwater plume; (O) transect measurements. In (C) dashed line is simple mixing curve of the freshwater (Fish Cove groundwater plume) and saltwater (Little Peconic Bay) end-members, solid line represents Model I linear regression of all points during the transect, excluding freshwater sample. Equation for this latter curve was $y=-23.0 x+625, r^{2}=0.97$ 
2001 sampling campaigns. Salinities at Fish Cove Sites 1 and $2(20.4 \pm 4.7$ and $23.0 \pm 4.1$ PSU respectively) were each significantly $(p<0.05$; TukeyKramer) lower than levels in North Sea Harbor $(26.7 \pm 1.5$ PSU) and Little Peconic Bay (28.2 \pm 0.5 PSU; Fig. 5A). Ammonium levels at Fish Cove Site 1 ranged from 11 to $250 \mu \mathrm{M}$, and averaged $61.7 \pm 69.3 \mu \mathrm{M}$ (aver-

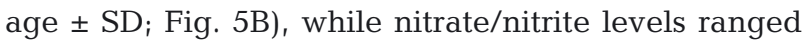
from 1.1 to $48 \mu \mathrm{M}$ and averaged $8.03 \pm 10.6 \mu \mathrm{M}$ (Fig. 5C). Further away from the groundwater plume in Fish Cove, at Site 2, levels of ammonium (10.1 \pm $10.1 \mu \mathrm{M}_{\text {; Fig. }}$ 5B) and nitrate/nitrite $(3.51 \pm 2.27 \mu \mathrm{M}$; Fig. 5C) were still elevated, but were significantly lower than at Fish Cove Site 1 ( $p<0.05$; TukeyKramer). North Sea Harbor inorganic nitrogen levels $($ ammonium $=3.53 \pm 3.55 \mu \mathrm{M}$; nitrate/nitrite $=3.55 \pm$

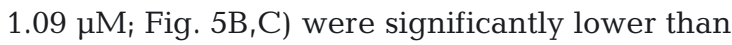
those within Fish Cove ( $p<0.05$; Tukey-Kramer), but were markedly higher than concentrations in Little Peconic Bay during our study (ammonium = $0.61 \pm 0.58 \mu \mathrm{M}$; nitrate/nitrite $=0.34 \pm 0.55 \mu \mathrm{M}$; Fig. 5B,C). Silicate displayed a trend similar to that of inorganic nitrogen, with high levels in Fish Cove (Site $1=35.9 \pm 19.3 \mu \mathrm{M}$; Site $2=32.9 \pm 8.58$ $\mu \mathrm{M}$; Fig. 5D), and low levels in Little Peconic Bay $(12.5 \pm 5.37 \mu \mathrm{M}$; Fig. 5D). In contrast, phosphate levels at Fish Cove Site $1(0.21 \pm 0.17 \mu \mathrm{M}$; Fig. 5E) were lower than those at all other sites (Fish Cove Site $2=0.60 \pm 0.60 \mu \mathrm{M}$; North Sea Harbor $=0.52 \pm$ $0.44 \mu \mathrm{M}$; Little Peconic Bay $=0.47 \pm 0.32 \mu \mathrm{M}$; Fig. 5E).

Differences in inorganic nitrogen and phosphorus concentrations resulted in $\mathrm{N}: \mathrm{P}$ ratios which varied above and below the Redfield N:P ratio of 16 . The consistently low inorganic nitrogen levels found in Little Peconic Bay contributed toward inorganic N:P ratios, which never exceeded 7 and averaged 2.7 during our study (Fig. 5F). North Sea Harbor inorganic N:P ratios varied seasonally above (spring and winter) and below (summer and fall) the Redfield ratio, and averaged 14 (Fig. 5F). Dissolved inorganic N:P ratios at Fish Cove Site 2 were well above Redfield N:P ratios on most occasions, and averaged 73 (Fig. 5F). Fish Cove Site 1 had DIN:DIP ratios which averaged 640, were always above the Redfield $\mathrm{N}: \mathrm{P}$, and were within the range of the DIN:DIP ratios found in the highflow groundwater plume (1000; Fig. 5F). In a similar manner, DIN:dissolved silicate ratios during this study were low at most stations (Fish Cove Site $2=0.4$; North Sea Harbor $=0.4$; Little Peconic Bay $=0.1$ ) but were significantly higher at Fish Cove Site 1 (3.3; p < 0.05; Tukey-Kramer; Fig. 5G).

\section{Inorganic nitrogen fluxes}

The relative importance of various inorganic nitrogen sources to the dissolved inorganic N (DIN) supply of Fish Cove and North Sea Harbor were quite different. In North Sea Harbor, groundwater, diffusive benthic fluxes, tidal exchange with Fish Cove, and tidal exchange with Little Peconic Bay each contributed similar amounts of DIN $(23,28,33$, and $11 \%$, respectively; Table 2). In contrast, in Fish Cove, the high-flow groundwater plume comprised the majority of DIN supply $(77 \%)$, while tidal exchange with North Sea Harbor, groundwater from the rest of the area, and diffusive benthic flux each represented small portions of the Fish Cove DIN supply $(16,4$, and $3 \%$, respectively; Table 2). For both locations, relative inputs of DIN from
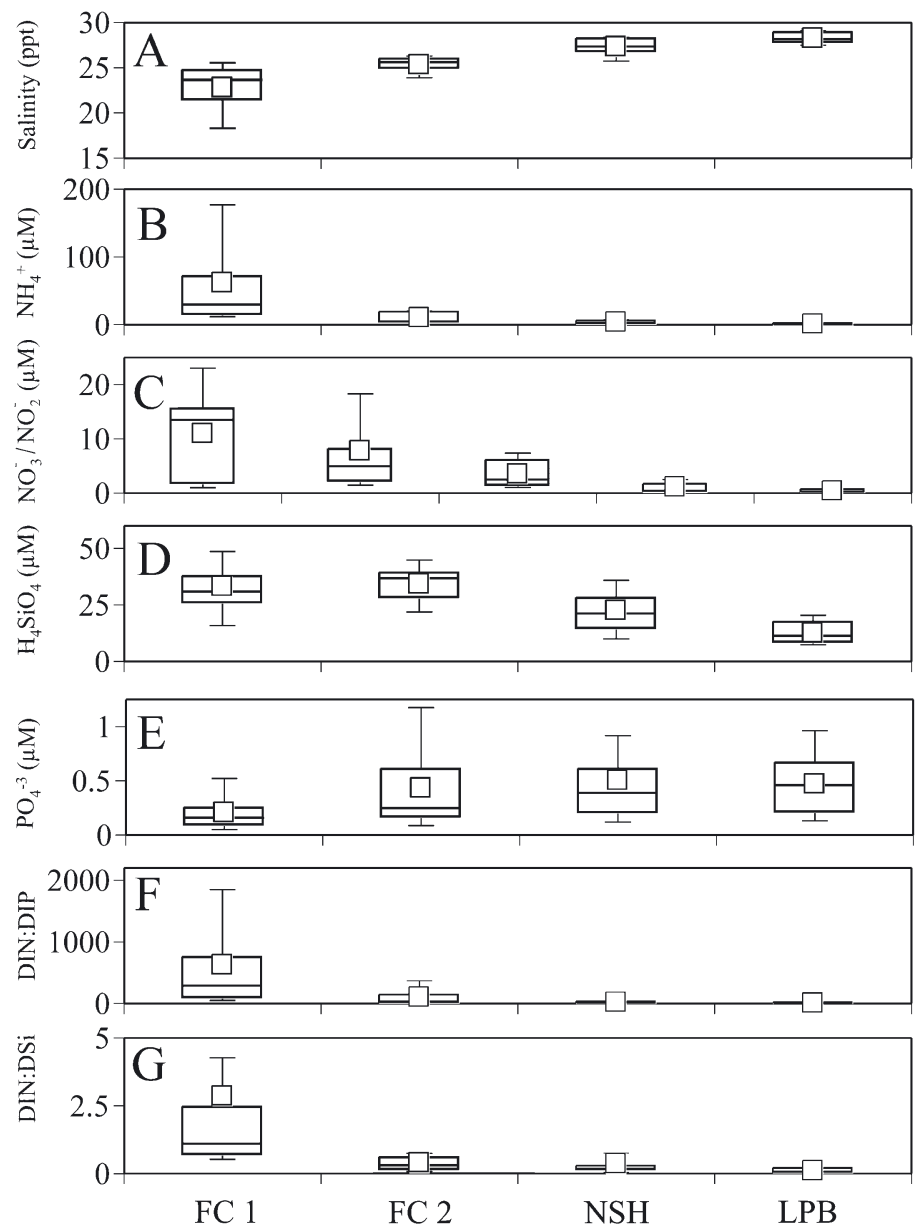

Fig. 5. Salinity, ammonium, nitrate/nitrite, silicate, phosphate, DIN:DIP ratios, and DIN:DSi ratios at Fish Cove Site 1 (FC 1), Fish Cove Site 2 (FC 2), North Sea Harbor (NSH) and Little Peconic Bay (LPB) during 2000 and 2001 sampling campaign. Box plots depict mean (small square within boxes), median (line within boxes), 25th and 75th percentiles (lower and upper edges of boxes) and 10 and 90th percentiles of data (lower and upper error bars) 
Table 2. Inorganic nitrogen fluxes from various sources entering North Sea Harbor (NSH) and Fish Cove (FC). Flow: freshwater flow rates; DIN: dissolved inorganic nitrogen. See 'Materials and methods' for details of calculations. LPB: Little Peconic Bay; -: benthic fluxes from sediment diffusion did not have associated flow rates or $\mathrm{N}$ concentrations

\begin{tabular}{|lcccc|}
\hline N source & $\begin{array}{c}\text { Flow } \\
\left(\mathrm{l} \mathrm{s}^{-1}\right)\end{array}$ & $\begin{array}{c}\text { DIN concen- } \\
\text { tration }(\mu \mathrm{M})\end{array}$ & $\begin{array}{c}\text { Flux } \\
\left(\mathrm{mM} \mathrm{N} \mathrm{s}^{-1}\right)\end{array}$ & $\begin{array}{c}\text { \% of total } \\
\text { input }\end{array}$ \\
\hline North Sea Harbor & & & & \\
Precipitation & 40.5 & 50 & 2.03 & 3 \\
Surface run-off & 1.97 & 55 & 0.11 & $<1$ \\
Groundwater & 232 & 60 & 13.9 & 23 \\
Benthic flux & - & - & 17.4 & 28 \\
Creeks & 99.5 & 10 & 1.00 & 2 \\
Tidal exchange, FC & 1500 & 14 & 20.3 & 33 \\
Tidal exchange, LPB & 6830 & 1 & 6.83 & 11 \\
Total & 8700 & - & 60.5 & 100 \\
Fish Cove & & & & \\
Precipitation & 4.63 & 50 & 0.23 & $<1$ \\
Surface run-off & 0.23 & 55 & 0.01 & $<1$ \\
Groundwater & 46.3 & 60 & 2.78 & 4 \\
Groundwater leachate plume & 50.9 & 1000 & 50.9 & 77 \\
Benthic flux & - & - & 1.97 & 3 \\
Tidal exchange, NSH & 1500 & 7 & 10.5 & 16 \\
Total & 1600 & - & 66.4 & 100 \\
\hline
\end{tabular}

atmospheric deposition, run-off and creeks were generally small $(<3 \%$ of the total supply; Table 2$)$. Although calculated DIN fluxes from precipitation at both locations were small ( 3 and $<1 \%$ of total for each NSH and FC, respectively), the absolute fluxes were in agreement with atmospheric deposition fluxes (wet and dry), which were calculated using the methods of Paerl (1993) and Hu et al. (1998).

\section{Phytoplankton abundance and diversity}

There were distinct differences in the levels of phytoplankton biomass in Fish Cove, North Sea Harbor, and Little Peconic Bay during this study (Fig. 6). Mean levels of chl $a$ in Fish Cove Site $1(5.8 \pm 3.4 \mu \mathrm{g}$ $\mathrm{l}^{-1}$ : avg. $\pm \mathrm{SD}_{\text {; Fig. }}$ ) were slightly lower than, but not statistically different from, levels in Fish Cove Site $2\left(8.5 \pm 5.6 \mu \mathrm{g} \mathrm{l}^{-1}\right.$; Fig. 6). However, these chl a concentrations were significantly greater than those in North Sea Harbor $\left(3.2 \pm 1.7 \mu \mathrm{g} \mathrm{l}^{-1}\right.$; $\mathrm{p}<0.01$; Tukey-Kramer; Fig. 6) and Little Peconic Bay (1.7 \pm $0.8 \mathrm{ug} \mathrm{l}^{-1} ; \mathrm{p}<0.001$; Tukey-Kramer; Fig. 6). Differences between Fish Cove sites and other sites were most notable during the summer months, when July and August chlorophyll levels at FC Sites 1 and 2 frequently exceeded $10 \mu \mathrm{g} \mathrm{l}^{-1}$. While sizefractionation of chlorophyll indicated that there was more biomass associated with larger $(>5 \mu \mathrm{m})$ phytoplankton in Fish Cove $(40 \%)$ compared to North Sea
Harbor and Little Peconic Bay $(30 \%$ for each), these differences were not significant.

There were also notable differences in the composition of microphytoplankton populations within various study sites (Fig. 7). Specifically, diatoms and dinoflagellates were common at all sites, but at varying densities. For example, while Fish Cove Site 2, North Sea Harbor and Little Peconic Bay hosted diatom populations with mean densities $>1000$ cells ml ${ }^{-1}$, mean diatom densities at Fish Cove Site 1 were significantly lower $(<500$ cells $\mathrm{ml}^{-1} ; \mathrm{p}<0.05$; Tukey-Kramer; Fig. 7). Additionally, there was a gradient in dinoflagellate density across our study sites, with the highest levels found closer to Fish Cove Site 1 (mean density $=530$ cells ml $\mathrm{m}^{-1}$ ) and the lowest density in Little Peconic Bay (mean density = 88 cells ml ${ }^{-1}$ ). Moreover, the dinoflagellate density at Fish Cove Site 1 were significantly higher than that in Little Peconic Bay ( $p<0.05$; Tukey-Kramer; Fig. 7). These differences were partly due to dinoflagellate blooms (>100 cells $\mathrm{ml}^{-1}$ ) of Prorocentrum minimum, Prorocentrum sp. Heterocapsa sp., and Alexandrium sp. at Fish Cove Site 1 during the summer and fall months. Finally, there were also modest levels of raphidophytes in Fish Cove (Sites 1 and 2; mean densities = 30 cells $\mathrm{ml}^{-1}$ ), and lower levels in North Sea Harbor (mean density $=7$ cells $\mathrm{ml}^{-1}$ ), while no raphidophytes were found in Little Peconic Bay (Fig. 7). The dominant raphidophyte genus was Chattonella sp.

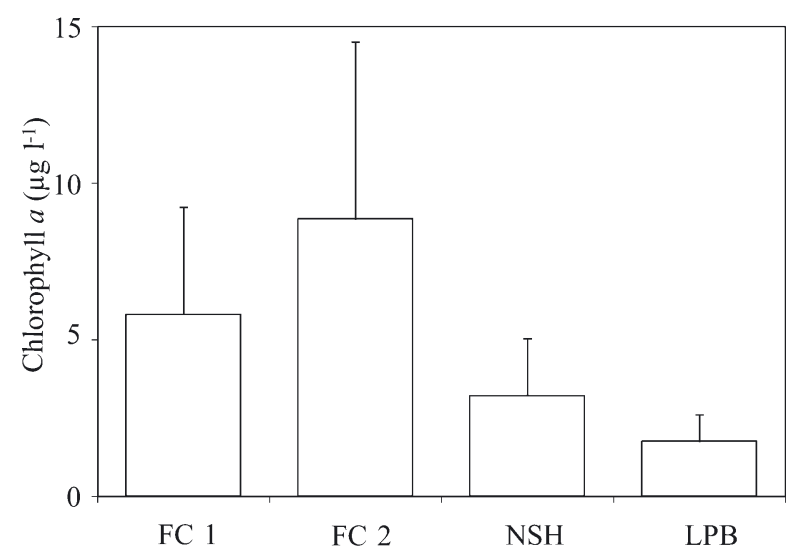

Fig. 6. Mean $( \pm \mathrm{SD})$ levels of chlorophyll $a$ at Fish Cove Site 1 (FC 1), Fish Cove Site 2 (FC 2), North Sea Harbor (NSH) and Little Peconic Bay (LPB) during 2000 and 2001 sampling campaigns 


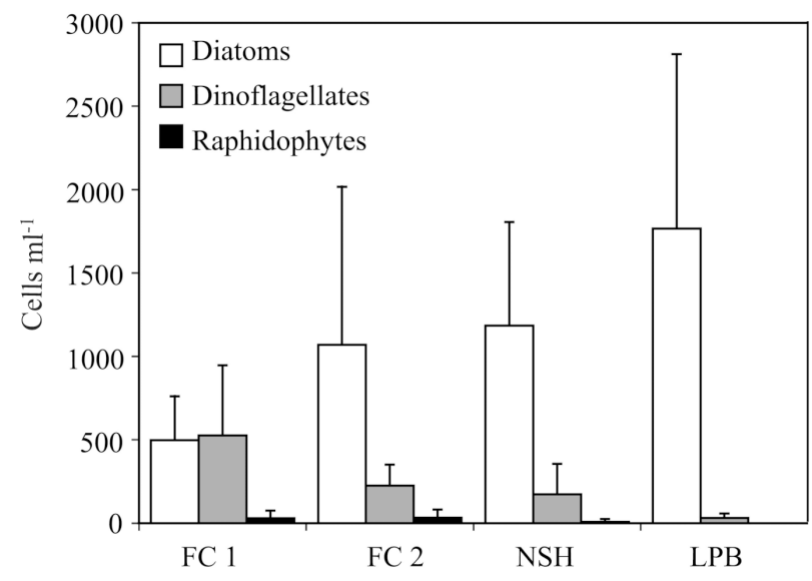

Fig. 7. Mean $( \pm \mathrm{SD})$ density of diatoms, dinoflagellates and raphidophytes at Fish Cove Site 1 (FC 1), Fish Cove Site 2 (FC 2), North Sea Harbor (NSH), and Little Peconic Bay (LPB) during 2000 and 2001 sampling campaigns control treatments when P was added (June, July, August, October; $\mathrm{p}<0.05$; $t$-test; Fig. 8).

\section{DISCUSSION}

Anthropogenically impacted groundwater is gaining recognition as a significant source of nutrients in shallow coastal environments. Research to date has demonstrated that septic tanks, sewage disposal, and agriculture can all significantly enhance nutrient levels in coastal groundwater (Persky 1986, Giblin \& Gaines 1990, Valiela et al. 1992, LaRoche et al. 1997, Corbett et al. 2000). In the current study, we amassed observational and experimental evidence demonstrating that discharge of groundwater containing landfill leachate can be a significant eutrophication process in coastal environments.

\section{Nutrient-enrichment experiments}

Phytoplankton communities of Fish Cove, North Sea Harbor, and Little Peconic Bay responded differently to the experimental addition of inorganic nitrogen and phosphorus during our study (Fig. 8). Moreover, responses to nutrient additions were consistent with observed DIN:DIP ratios measured at each site. For example, in Little Peconic Bay, where DIN:DIP ratios were consistently below the Redfield ratio (Fig. 5F), the phytoplankton community experienced significantly increased growth rates during inorganic nitrogen additions relative to control treatments during every experiment conducted from April through October 2000 (p < 0.05; Student's $t$-test; Fig. 8). Similarly, inorganic nitrogen additions significantly augmented phytoplankton growth rates in North Sea Harbor relative to control treatments during most experiments ( $p<0.05$; $t$-test; Fig. 8). The exception to this trend occurred in late summer, as $\mathrm{N}$ additions did not alter phytoplankton growth rates in North Sea Harbor during August and September (Fig. 8), when ambient DIN levels and DIN:DIP ratios were high (Fig. 5F). In stark contrast to North Sea Harbor and Little Peconic Bay, N additions made to Fish Cove phytoplankton communities never enhanced algal growth rates (Fig. 8). Instead, Fish Cove communities, which were exposed to a mean DIN:DIP ratio of 640 during this study (Fig. 5F), appeared to be nutrientreplete (April, May, September) or experienced significantly enhanced growth rates relative to
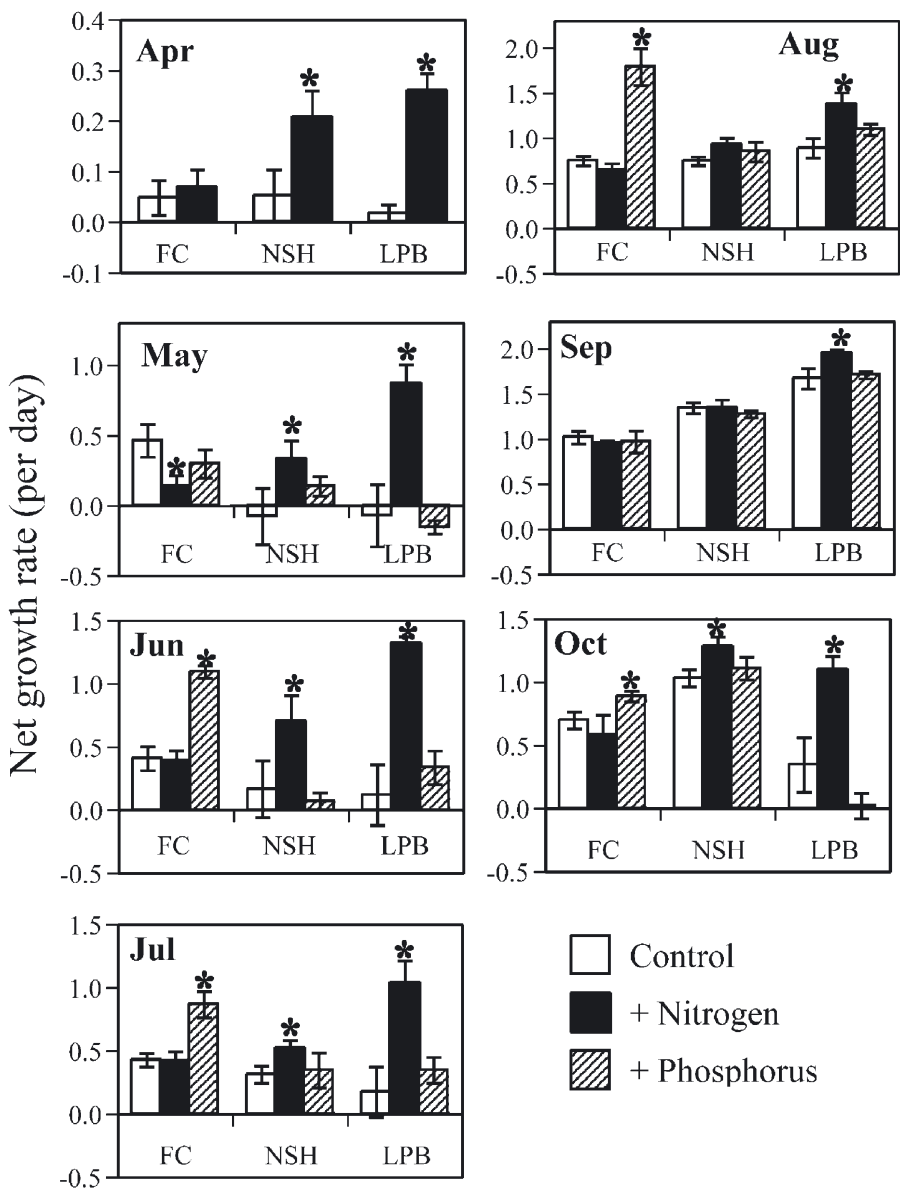

Fig. 8. Mean $( \pm \mathrm{SD})$ net growth rates of phytoplankton communities following addition of nitrogen (black bars) or phosphorus (gray bars) or with no addition (control; white bars) at Fish Cove (Site 1, FC ), North Sea Harbor (NSH) and Little Peconic Bay (LPB). Experiments were conducted monthly from April through October of 2000. Asterisks indicate treatments which yielded growth rates significantly greater than controls $(p<0.05)$ 


\section{Delivery of groundwater-borne nutrients to surface waters}

Nitrate is generally the principal form of nitrogen found in the aquifer surrounding most coastal areas of the NE USA (Valiela \& Costa 1988, Giblin \& Gaines 1990), including Long Island (Capone \& Bautista 1985, Gobler \& Sañudo-Wilhemy 2001). While nitrate and nitrite were the dominant form of inorganic nitrogen found in much of the groundwater entering Fish Cove and North Sea Harbor, nearly all the inorganic nitrogen entering the SW corner of Fish Cove was ammonium (Figs. 2 \& 3). High levels of ammonium found in this region, along with the high DOC concentrations and low nitrate/nitrite and dissolved oxygen levels (Fig. 2), are classic indicators of landfill leachate plumes (Cozzarelli et al. 1990, 2000, Bjerg et al. 1995, Christensen et al. 2001), suggesting that this groundwater originated from the nearby $(500 \mathrm{~m})$ unlined North Sea landfill. Landfills are typically sites of high levels of organic nitrogen and microbial activity which combine to rapidly produce ammonium and consume oxygen in leachate plumes (Christensen et al. 2001). The absence of oxygen in the plume prevents nitrification of groundwater ammonium (Koike \& Hattori 1978), a process common in NE USA aquifers (Gobler \& Sañudo-Wilhelmy 2001). Moreover, the low oxygen levels and high DOC concentrations in this groundwater are likely to support active denitrification of nitrate present in the groundwater (Seitzinger 1988) or, alternatively, the reduction of nitrate to ammonium (Tobias et al. 2001). These processes would account for the extremely low levels of nitrate/nitrite in the groundwater plume (Fig. 2) compared to groundwater in other parts of Fish Cove and North Sea Harbor.

Groundwater flow rates measured through much of Fish Cove and North Sea Harbor were generally within the range of rates previously determined for estuaries on Long Island (Bokuniewicz 1980, Paulsen et al. 1998, Montuçon \& Sañudo-Wilhemly 2001). In contrast, groundwater flow rates in the SW portion of Fish Cove exceed any level previously reported for Long Island, and may be attributable to the extremely steep hydraulic gradient in this region, the absence of intertidal plants (e.g. Spartina alterniflora, Phragmites australis) surrounding the region, the coarse sediments, and the leachate plume originating from the North Sea landfill. Perimeters of landfills with leachate plumes have previously been noted as having similar high-flow springs which seep out of coarse sediments (Freeze \& Cherry 1979). The rapid flow rates of groundwater containing nearly $1 \mathrm{mM}$ of ammonium creates a tremendous nitrogen flux and accounts for this leachate plume being the primary source of inorganic nitrogen to Fish Cove (Table 2).

\section{Impact of groundwater flow on water quality and phytoplankton dynamics}

Quantification of inorganic nitrogen fluxes during this study indicated that the groundwater leachate plume entering Fish Cove was the primary source of inorganic nitrogen to this embayment (77\% of supply; Table 2). The samples collected from the Fish CoveLittle Peconic Bay transect yielded a salinity-ammonium regression with a y-intercept of $625 \mu \mathrm{M}$ (Fig. 4C). This freshwater DIN source comprises $66 \%$ of the leachate plume ammonium concentration $\left(942 \mu \mathrm{M}_{\text {; }}\right.$ Fig. 2), supporting the conclusion that the plume was the primary DIN source to the region. In addition to natural variability, the small differences observed between the flux calculations (plume $=77 \%$ of Fish Cove N-supply) and the intercept-derived freshwater source $(66 \%)$ could indicate active biological removal of ammonium within the water column (Sharp et al. 1984). In contrast to Fish Cove, groundwater supplied about a quarter of the inorganic nitrogen to neighboring North Sea Harbor. Since most of the inorganic nitrogen in Fish Cove originated from the North Sea landfill leachate plume, it can be argued that this plume was also a significant source of inorganic nitrogen to North Sea Harbor, as $33 \%$ of the NSH inorganic nitrogen came from tidal exchange with Fish Cove (Table 2). The conclusion that most of the inorganic nitrogen in Fish Cove was supplied by groundwater is consistent with previous research in the Peconic Estuary (LaRoche et al. 1997) and in other NE US estuaries which have been impacted by coastline expansion (Giblin \& Gaines 1990, Valiela et al. 1992, Staver \& Brinsfield 1996). Finally, the high levels of DOC in groundwater entering Fish Cove (Fig. 2) suggest that dissolved organic nitrogen (DON) may also have been enriched in this seepage. If this were the case, the groundwater entering Fish Cove is probably an even more important source of total dissolved nitrogen to this system, since it is likely that most of the groundwater entering other parts of our study area had low levels of DON (Gobler \& Sañudo-Wilhelmy 2001).

Previous studies have characterized the Peconic Estuary as having low levels of inorganic nutrients $(\sim 1 \mu \mathrm{M})$ and chl a $\left(\sim 2 \mu \mathrm{g} \mathrm{l}^{-1}\right)$, and a phytoplankton community dominated by diatoms and seasonally limited by the supply of nitrogen (Hardy 1976, Bruno et al. 1980, 1983, Turner et al. 1983). Similar studies of enclosed embayments within the Peconic Estuary system have found levels of algal biomass and inorganic nitrogen to be slightly higher than the main basins of the estuary, but have also found nitrogen to limit phytoplankton growth rates (Gobler 1999, Gobler \& Sañudo-Wilhemy 2001). Many of the findings of the current study are consistent with this prior work. Mod- 
est levels of nutrients and phytoplankton biomass were present in North Sea Harbor and Little Peconic Bay (Figs. 5 \& 6). Moreover, the micro-phytoplankton communities in these regions always contained more diatoms than dinoflagellates, and were chronically limited by $\mathrm{N}$ (Fig. 8). In stark contrast, Fish Cove displayed water-column characteristics and a phytoplankton community, which were a marked departure from any previous observation made in Long Island waters.

Fish Cove is a eutrophic environment. The plume of landfill leachate entering it is the primary source of inorganic nitrogen to this embayment (Table 2) and contributes toward inorganic nutrient levels which exceed concentrations previously reported for surface waters of Long Island estuaries (Hardy 1976, Bruno et al. 1980, 1983, Turner et al. 1983, Gobler \& SañudoWilhemy 2001). This input of nitrogen seemed to support levels of phytoplankton biomass which are consistently elevated relative to neighboring North Sea Harbor (Fig. 6). Fish Cove also fosters an algal community which is generally nutrient-replete or phosphoruslimited (Fig. 8), a phenomenon which has never been observed within the Peconic Estuary system. The extremely high DIN:DIP ratios found in Fish Cove (mean $=640$; Fig. 5F) were also indicative of a phytoplankton community that was probably N-replete and potentially P-limited. Although Fish Cove is an isolated embayment, strong tidal flushing of this bay (estimated residence time $<3$ d) probably mitigates the accumulation of nitrogen and algal biomass beyond the already high levels observed.

The site of leachate discharge in Fish Cove also seems to impact the composition of the microphytoplankton population there. In contrast to other stations, which had micro-phytoplankton communities dominated by diatoms, Fish Cove Site 1 hosted a significantly lower level of diatoms and an abundance of dinoflagellates which exceeded densities at other stations (Fig. 7). More specifically, Fish Cove Site 1 hosted blooms of phytoplankton which have been previously been identified as harmful, such as Prorocentrum minimun, Alexandrium sp., Heterocapsa sp., and Chattonella sp. (Smayda 1990, Oda et al. 1992, Matsuyama 1999). Since Fish Cove Site 1 also has extremely high levels of dissolved inorganic nitrogen (mean $=70 \mu \mathrm{M}$ ), and receives inputs of groundwater enriched in DOC (and presumably DON), the proliferation of these algae supports the supposition that eutrophication and organic loading can promote the proliferation of harmful algal blooms (Smayda 1990, Glibert et al. 2001, Anderson et al. 2002). Moreover, the presence of these phytoplankton at lower densities within Fish Cove Site 2 and North Sea Harbor suggests that Fish Cove Site 1 could serve as a seed bed for tidally transporting harmful algal species to neighboring bodies of water.
There are many constituents found within landfill leachate, such as trace metals and organic compounds, which may affect phytoplankton species diversity and composition. However, the high levels of inorganic nutrients in groundwater entering Fish Cove clearly impact phytoplankton growth rates and biomass in this region. In addition, trends in microalgal community composition observed during this study may have been impacted by the ratios of DIN to dissolved silicate (DSi) in groundwater delivered to the region. Healthy diatom cells generally contain 1 mole of silicon for each mole of cellular nitrogen (Brzezinski 1985). Eutrophication in other coastal bodies of water has previously been cited as a factor contributing to a decline in diatom abundance and increases in populations of non-silicon-requiring algae, as nitrogen loading increases DIN:DSi ratios (Doering et al. 1989, Smayda 1990, Turner et al. 1998). The ratios of DIN:DSi in North Sea Harbor and Little Peconic Bay $(<1)$ suggest that nitrogen would limit diatom growth rates, a conclusion consistent with our nutrient-enrichment experiments (Fig. 5G). In contrast, the high delivery rates of nitrogen at Fish Cove Site 1 yielded an elevated DIN:DSi ratio $(3.3$; Fig. 5 G) that could have led to $\mathrm{Si}$ limitation of diatoms, and caused the reduced diatom densities within this region (Fig. 7). While it would have been preferable to have experimentally evaluated the importance of $\mathrm{Si}$ additions to this system, a dearth of previous research on Si-limitation in Long Island estuaries precluded us from anticipating the observed trends.

\section{Water-quality implications for coastal landfills}

Chemical constituents within many landfill leachate plumes often traverse relatively short distances $(\sim 1000 \mathrm{~m})$ due to natural attenuation processes and dispersion, and thus may not reach all coastal surface waters (Christensen et al. 2001). However, in the permeable, coarse-sand aquifers found in the NE United States, leachate plumes may spread distances exceeding $5000 \mathrm{~m}$ (Kimmel \& Braids 1974, 1980). High groundwater flow rates due to steep hydraulic gradients, which are common within some coastal aquifers (Gobler \& Sañudo-Wilhelmy 2001), may further extend the length of landfill leachate plumes (Freeze \& Cherry 1979). Moreover, it has been established that, unlike many constituents of landfill leachate, which degrade with time, ammonium is a long-term pollutant that remains present at elevated levels in plumes over time (Christensen et al. 2001). Hence, nearshore landfills, which are unlined and/or uncapped, and have extensive leachate plumes which reach surface waters, may continue to be a significant source of coastal eutrophi- 
cation for decades to come. The efficient recycling of nitrogen in shallow marine ecosystems via processes such as diffusive benthic fluxes (Nixon \& Pilson 1983) would further extend the impact of N-loading from leachate plume discharge.

Surface waters surrounding large coastal urban centers may be the regions most impacted by landfill leachate plumes. For example, New York City has hosted over $180 \mathrm{~km}^{2}$ of municipal solid-waste landfills over the past 2 centuries (Walsh \& LaFleur 1995). Since the majority of these landfills were unlined and constructed on tidal wetlands with fine-grain deposits, lateral transport of leachate to the surrounding surface water is common (Walsh \& LaFleur 1995). Finally, a series of recent reports documenting coastal landfills with leachate entering surface waters (Striebel et al. 1991, Chu et al. 1994, Furukawa et al. 1994, Walsh \& LaFleur 1995, Nobes et al. 2000, Barlaz et al. 2002) suggests that such plumes could be an important, but previously undocumented, source of eutrophication in aquatic systems around the world.

Acknowledgements. We thank Ron Paulsen and Dan O'Rouke for providing ultrasonic groundwater seepage measurements. We are grateful for the assistance of the following Southampton College students during this project: Derek Groat, John Reichert, Jim Berg, Carla Hinchliffe, Tracy Beyer, Annik Baker, and Juli Rowehl. We thank the Southampton College Marine Station for field and laboratory support. We thank V. N. de Jonge and 3 anonymous reviewers for helpful comments on this manuscript. C.J.G. also thanks fellow DIALOG IV participants Craig Tobias and D. Reide Corbett, as well as Dianna Berry, for critical manuscript reviews. We thank Ed Himelblau for graphic assistance with figures. This research was supported by New York Sea Grant awards R/CMB-25 and R/CMB-26 to C.J.G. and by the Research Awards Committee of Southampton College, Long Island University.

\section{LITERATURE CITED}

Anderson DM, Glibert PM, Burkholder JM (2002) Harmful algal blooms and eutrophication: nutrient sources, composition and consequences. Estuaries 4B:704-726

Barlaz MA, Rooker AP, Kjeldsen P, Gabr MA, Borden RC (2002) Critical evaluation of factors required to terminate the postclosure monitoring period at solid waste landfills. Environ Sci Technol 36:3457-3464

Belanger T, Montgomery M (1992) Seepage meter errors. Limnol Oceanogr 37:1787-1795

Benner R, Strom M (1993) A critical evaluation of the analytical blank associated with DOC measurements by hightemperature catalytic oxidation. Mar Chem 41:153-160

Bjerg PL, Ruegge K, Pedersen JK, Christensen TH (1995) Distribution of redox-sensitive groundwater quality parameters downgradient of a landfill (Grindsted, Denmark). Environ Sci Tech 29:1387-1394

Bokuniewicz HJ (1980) Groundwater seepage into Great South Bay, New York. Estuar Coast Mar Sci 10:437-444

Borum J (1996) Shallow waters and land/sea boundaries. Coast Estuar Stud 52:1-19
Bruno SF, Staker RD, Sharma GM (1980) Dynamics of phytoplankton productivity in the Peconic Bay estuary, Long Island. Estuar Coast Mar Sci 10:247-263

Bruno SF, Staker RD, Sharma GM, Turner JT (1983) Primary productivity and phytoplankton size fraction dominance in a temperate North Atlantic estuary. Estuaries 6:200-211

Brzezinski MA (1985) The Si:C:N ratio of marine diatoms: interspecific variability and the effect of some environmental variables. J Phycol 21:347-357

Cable JE, Burnett WC, Chanton JP, Corbett DR, Cable PH (1997) Field evaluation of seepage meters in the coastal marine environment. Estuar Coast Shelf Sci 45:367-375

Capone DG, Bautista MF (1985) A groundwater source of nitrate in nearshore marine sediments. Nature 313: $214-216$

Christensen TH, Kjeldsen P, Bjerg PL, Jensen DL, Christensen JB, Baun A, Albrechtsen HJ, Heron G (2001) Biogeochemistry of landfill leachate plumes. Appl Geochem 16:659-718

Chu LM, Cheung KC, Wong MH (1994) Variations in the chemical-properties of landfill leachate. Environ Manag 18:105-117

Corbett DR, Kump L, Dillon K, Burnett W, Chaton J (2000) Fate of wastewater-borne nutrients under low discharge conditions in the subsurface of the Florida Keys, USA. Mar Chem 69:99-115

Cornell S, Rendell A, Jickells T (1995) Atmospheric inputs of dissolved organic nitrogen to the oceans. Nature 376 : 243-246

Cozzarelli IM, Eganhouse RP, Baedecker MJ (1990) Transformation of monoaromatic hydrocarbons to organic acids in anoxic groundwater environment. Environ Geol Water Sci 16:135-141

Cozzarelli IM, Suflita JM, Ulrich GA, Harris SH, Scholl MA, Schottmann JL, Christenson S (2000) Geochemical and microbiological methods for evaluating anaerobic processes in an aquifer contaminated by landfill leachate. Environ Sci Technol 34:4025-4033

de Jonge VN, Elliott M, Orive E (2002) Causes, historical development, effects and future challenges of a common environmental problem: eutrophication. Hydrobiologia 475:1-19

Doering PH, Oviatt CA, Beatty LL, Banzon VF, Rice R, Kelly SP, Sullivan BK, Frithsen JB (1989) Structure and function in a model coastal ecosystem: silicon, the benthos and eutrophication. Mar Ecol Prog Ser 52:287-299

EPA (Environmental Protection Agency) (1984) Hazardous ranking score report (HRS). United States Environmental Protection Agency (Region II), Washington, DC

EPA (Environmental Protection Agency) (1989) Record of decision, EPA/ROD/R02-89/085. United States Environmental Protection Agency (Region II), Washington, DC

EPA (Environmental Protection Agency) (1997) Municipal solid waste factbook, version 4.0; Reb. 530-C-97-001. United States Environmental Protection Agency, Washington, DC

Fetter CW (1994) Applied hydrogeology. Prentice-Hall, Englewood Cliffs, NJ

Fischer HB, List EJ, Koh RCY, Imberger J, Brooks NH (1979) Mixing in inland and coastal waters. Academic Press, New York

Freeze RA, Cherry JA (1979) Groundwater. Prentice-Hall, Englewood Cliffs, NJ

Furukawa K, Ryu SL, Fujita M, Fukunaga I (1994) Nitrogen pollution of leachate at a sea-based solid waste disposal site and its nitrification treatment by immobilized acclimated nitrifying sludge. J Ferment Bioeng 77:413-418 
Giblin AE, Gaines AG (1990) Nitrogen inputs to a marine embayment: the importance of groundwater. Biogeochemistry 10:309-328

Glibert PM, Magnien R, Lomas MW, Alexander J, Fan C, Haramoto E, Trice M, Kana TM (2001) Harmful algal blooms in the Chesapeake and coastal bays of Maryland, USA: comparison of 1997, 1998, and 1999 events. Estuaries 24:875-883

Gobler CJ (1999) A biogeochemical investigation of Aureococcus anophagefferens blooms: interactions with organic nutrients and trace metals. $\mathrm{PhD}$ thesis, State University of New York at Stony Brook

Gobler CJ, Sañudo-Wilhemy SA (2001) Temporal variability of groundwater seepage and brown tide blooms in a Long Island embayment. Mar Ecol Prog Ser 217:299-309

Guillard RRL (1973) Division rates. In: Stein JR (eds) Handbook of phycological methods, culture methods, and growth measurements. Cambridge Press, Cambridge, p 289-312

Hardy CD (1976) A preliminary description of the Peconic Bay Estuary. Marine Sciences Research Center, State University of New York at Stony Brook. Special Report 3. SUNY Press, Stony Brook, NY

Hasle GR (1978) The inverted microscope method. Monogr Oceanogr Methodol 6:88-96

Howes BL, Goehringer DD (1994) Porewater drainage and dissolved organic carbon and nutrient losses through the intertidal creekbanks of a New England salt marsh. Mar Ecol Prog Ser 114:289-301

Howes BL, Schlezinger DR, Millham NP, Hampson G, Goehringer DP, Aubrey S (1998) Oxygen uptake and nutrient regeneration in the Peconic Estuary. Final report. Suffolk County Department of Health Services, Office of Ecology, Riverhead, NY

Hu HL, Chen HM, Nikoladia NP, Miller DR, Yang X (1998) Estimation of nutrient atmospheric deposition to Long Island Sound. Water Air Soil Pollut 105:521-538

Johannes RE (1980) The ecological significance of submarine discharge of groundwater. Mar Ecol Prog Ser 3:365-373

Jones MN (1984) Nitrate reduction by shaking with cadmium: alternative to cadmium columns. Water Res 18:643-646

Kimmel GE, Braids OC (1974) Leachate plumes in a highly permeable aquifer. Ground Water 12:388-392

Kimmel GE, Braids OC (1980) Leachate plumes in groundwater from Babylon and Islip landfills, Long Island, New York. Prof Pap US Geol Surv 1085:1-38

Kinney EH, Roman CT (1998) The response of primary producers to nutrient enrichment in a shallow estuary. Mar Ecol Prog Ser 162:89-98

Koike I, Hattori A (1978) Denitrification and ammonia formation in anaerobic coastal sediments. Appl Environ Microbiol 35:278-282

LaRoche J, Nuzzi R, Waters R, Wyman K, Falkowski PG, Wallace DWR (1997) Brown tide blooms in Long Island's coastal waters linked to variability in groundwater flow. Glob Change Biol 3:397-410

Lee DR (1977) A device for measuring seepage flux in lakes and estuaries. Limnol Oceanogr 22:140-147

Lee V, Olsen S (1985) Eutrophication and management initiatives for the control of nutrient inputs to Rhode Island coastal lagoons. Estuaries 8:191-202

Matsuyama Y, Uchida T, Honjo T (1999) Effects of harmful dinoflagellates, Gymnodinium mikimotoi and Heterocapsa circularisquama, red-tide on filtering rate of bivalve molluscs Fish Sci 65:248-253

McClelland JW, Valiela I, Michener RH (1997) Nitrogenstable isotope signatures in estuarine food webs: a record of increasing urbanization in coastal watersheds. Limnol Oceanogr 42:930-937

Montluçon D, Sañudo-Wilhelmy SA (2001) Influence of groundwater seepage on nutrient and metal concentrations in a coastal environment: Flanders Bay, Long Island, NY. Environ Sci Technol 35:480-486

Nixon SW, Pilson MEQ (1983) Nitrogen in estuarine and coastal marine ecosystems. In: Carpenter EJ, Capone, DG (eds) Nitrogen in the marine environment. Academic Press, New York, p 411-458

Nobes DC, Armstrong MJ, Close ME (2000) Delineation of a landfill leachate plume and flow channels in coastal sands near Christchurch, New Zealand, using a shallow electromagnetic survey method. Hydrogeol J 8:328-336

Oda T, Ishimatsu A, Shimada M, Takeshita S, Muramatsu T (1992) Oxygen-radical-mediated toxic effects of the red tide flagellate Chattonella marina on Vibrio alginolyticus. Mar Biol 112:505-509

Paerl HW (1993) Emerging role of atmospheric nitrogen deposition in coastal eutrophication: biogeochemical and trophic perspectives. Can J Fish Aquat Sci 50:2254-2269

Parsons TR, Maita Y, Lalli CM (1984) A manual of chemical and biological methods for seawater analysis. Pergamon Press, Oxford

Paulsen RJ, Smith CF, Wong, TF (1998) Defining freshwater outcrops in West Neck Bay, Shelter Island, New York, using direct contact resistivity measurements and transient underflow measurements. In: Hanson GN (ed) Geology of Long Island and metropolitan New York. Proc Meeting Long Island Geol, SUNY Press, Stony Brook, NY, p 421-427

Paulsen RJ, Smith CF, O'Rouke D, Wong TF (2001) Development and evaluation of an ultrasonic groundwater seepage meter. Ground Water 39:904-911

Persky JH (1986) The relation of groundwater quality to housing density, Cape Cod, Massachusetts. US Geological Survey Water Resources Investigations Report 86-4093. US Geological Survey, Boston, MA

Puls RW, Paul CJ (1995) Low-flow purging and sampling of ground water monitoring wells with dedicated systems. Ground Water Monitoring Rev 15:116-123

Puls RW, Powell RM (1992) Acquisition of representative groundwater quality samples for metals. Ground Water Monit Rev 12:167-176

Richardson K, Jørgensen BB (1996) Eutrophication: definition, history, and effects. Coast Estuar Stud 52:1-19

Schubert CE (1998) Areas contributing ground water to the Peconic Estuary, and ground-water budgets for the North and South Forks and Shelter Island, Eastern Suffolk County, New York. US Geological Survey Water Resources Investigations Report 97-4136. US Geological Survey, Coram, NY

Seitzinger SP (1988) Denitrification in fresh-water and coastal marine ecosystems: ecological and geochemical significance. Limnol Oceanogr 33:702-724

Sewell PL (1982) Urban groundwater as a possible nutrient source for an estuarine benthic algal bloom. Estuar Coast Shelf Sci 15:569-576

Sharp JH, Pennock JR, Church TM, Tramontano JM, Cifuentes LA (1984) The estuarine interaction of nutrients, organics, and metals: a case study in the Delaware Estuary. In: Kennedy VS (ed) The estuary as a filter. Academic Press, New York, p 241-257

Short FT, Burdick DM (1996) Quantifying eelgrass habitat loss in relation to housing development and nitrogen loading in Waquoit Bay, Massachusetts. Estuaries 19:730-739 Smayda TJ (1990) Novel and nuisance phytoplankton blooms 
in the sea: evidence for a global epidemic. In: Graneli E, Sundstrom B, Edler L, Anderson DM (eds) Toxic marine phytoplankton. Elsevier, New York, p 29-40

Staver KW, Brinsfield RB (1996) Seepage of groundwater nitrate from a riparian agrosystem into the Wye River Estuary. Estuaries 19:359-370

Steenhuis TS, Jackson CD, Kung SKG, Brutsaert WH (1985) Measurement of groundwater recharge on eastern Long Island, NY, USA. J Hydrol 79:145-169

Striebel T, Schafer W, Pfeiffer S (1991) How does landfill leachate affect the chemical processes in a lake system downgradient from a landfill site? Aquat Sci 53:346-366

Tobias CR, Macko SA, Anderson IC, Canuel EA, Harvey JW (2001) Tracking the fate of a high concentration groundwater nitrate plume through a fringing marsh: a combined groundwater tracer and in situ isotope enrichment study. Limnol Oceanogr 46:1977-1989

Editorial responsibility: Otto Kinne (Editor), Oldendorf/Luhe, Germany
Turner JT, Bruno SF, Larson RJ, Staker RD, Sharma GM (1983) Seasonality of plankton assemblages in a temperate estuary. Mar Ecol 4:81-99

Turner RE, Qureshi N, Rabalais NN, Dortch Q, Justic D, Shaw RF, Cope J (1998) Fluctuating silicate:nitrate ratios and coastal plankton food webs. Proc Natl Acad Sci USA 95:13048-13051

Valiela I, Costa J (1988) Eutrophication of Buttermilk Bay, a Cape Cod coastal embayment: concentrations of nutrients and watershed nutrient budgets. Environ Manag 12: $539-551$

Valiela I, Foreman K, Lamontagne M, Hersh D and 8 others (1992) Coupling of watersheds and coastal waters: sources and consequences of nutrient enrichment in Waaquoit Bay, Massachusetts. Estuaries 15:443-457

Walsh DC, LaFleur RG (1995) Landfills in New York City1844-1994. Ground Water 33:556-560

Submitted: July 19, 2002; Accepted: February 11, 2003 Proofs received from author(s): June 4, 2003 